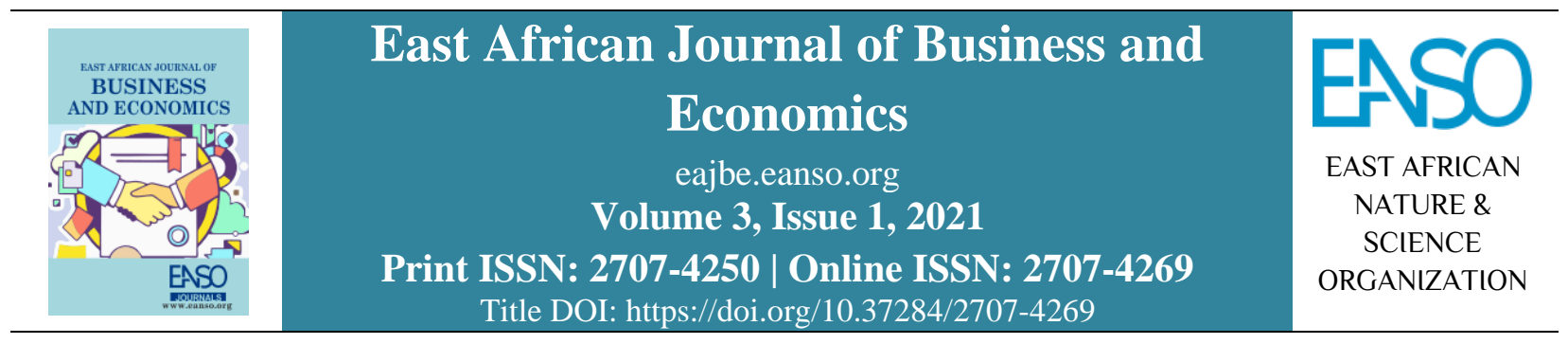

Original Article

\title{
Moderating Effect of Financial Literacy on Relationship between Anchoring and Investment Decision among SMEs in Nairobi County
}

\author{
Leah Jemutai Barno $^{1 *}$, Dr. Josephat Cheboi ${ }^{1}$, Dr. Catherine Muganda ${ }^{1}$ \\ ${ }^{1}$ Moi University, P. O. Box 3900-30100, Eldoret, Kenya. \\ * ORCID: https://orcid.org/0000-0003-4549-7471; Correspondence email: jemutaileah@ yahoo.com.
}

Article DOI: https://doi.org/10.37284/eajbe.3.1.305

\section{Date Published: ABSTRACT}

24 March 2021 Purpose: Moderating effect of Financial Literacy on Relationship between Anchoring and Investment Decision among SMEs in Nairobi County. The

Keywords: study was premised on the regrets theory. Methods/materials: The positivism paradigm was deployed. The study adopts an explanatory research design. The

Anchoring, target population was 102,821 firm owners. A sample of 383 respondents was selected using the stratified random sampling technique. Multiple hierarchical $\begin{aligned} \text { Financial Literacy, } & \text { linear regression models were used to establish moderating effects of financial } \\ \text { Investment Decision, } & \text { literacy. Findings: Anchoring factors positively influenced investment decision }\end{aligned}$

SMEs. $\quad(\beta=0.173, p<0.05)$. The study also found that financial literacy moderates the relationship anchoring and investment decisions $\left(\beta=.92, p>0.05, \Delta R^{2}=\right.$ .07). Conclusion/Practical implication; Anchoring enhance investment decisions among the small and medium enterprise. In addition, high financial literacy improves the relationship between anchoring behaviour and investment decisions among SMEs. This would enhance better decision investment decisions improving the financial performance of the SMEs.

\section{APA CITATION}

Barno, L. J., Cheboi, J., \& Muganda, C. (2021). Moderating Effect of Financial Literacy on Relationship between Anchoring and Investment Decision among SMEs in Nairobi County. East African Journal of Business and Economics, 3(1), 65-81. https://doi.org/10.37284/eajbe.3.1.305

\section{CHICAGO CITATION}

Barno, Leah Jemutai, Josephat Cheboi, and Catherine Muganda. 2021. "Moderating Effect of Financial Literacy on Relationship between Anchoring and Investment Decision among SMEs in Nairobi County". East African Journal of Business and Economics 3 (1), 65-81. https://doi.org/10.37284/eajbe.3.1.305.

\section{HARVARD CITATION}

Barno, L. J., Cheboi, J. and Muganda, C. (2021) "Moderating Effect of Financial Literacy on Relationship between Anchoring and Investment Decision among SMEs in Nairobi County", East African Journal of Business and Economics, 3(1), pp. 65-81. doi: 10.37284/eajbe.3.1.305. 


\section{IEEE CITATION}

L. J. Barno, J. Cheboi, and C. Muganda, "Moderating Effect of Financial Literacy on Relationship between Anchoring and Investment Decision among SMEs in Nairobi County”, EAJBE, vol. 3, no. 1, pp. 65-81, Mar. 2021.

\section{MLA CITATION}

Barno, Leah Jemutai, Josephat Cheboi, and Catherine Muganda. "Moderating Effect of Financial Literacy on Relationship between Anchoring and Investment Decision among SMEs in Nairobi County". East African Journal of Business and Economics, Vol. 3, no. 1, Mar. 2021, pp. 65-81, doi:10.37284/eajbe.3.1.305

\section{INTRODUCTION}

The investment decision is the process of making a choice amongst alternatives which involves capital outlay for future cash flows in the long-term growth of a business. Investment decisions are a part of strategic decision-making in every enterprise because new investment projects essentially affect future economic results and the enterprise's prosperity (Schwab, 2017). Investment decisions regarding the various forms of capital input have also been positively linked to financial performance; the stochastic outcome of a firm's own investments in aspects such as physical capital, human capital, research and development expenditure increases firm's production capacity hence boosting its financial performance (Levasseur, 2002).

The relationship between the prudent investment decision making capability of a firm's managers and its advantage in analysing a target investments financial performance is vital. Managers are perceived to have more information than other investors regarding an investment; thus, managers are vital in making prudent investment decisions that can lead to better performance of a company in both financial and non-financial parameters (Akintoye \& Olowolaju, 2008). Thus, managers behaviour is motivated by a variety of psychological heuristics and biases such as anchoring that contribute to decision making in investment (Ojwang, 2015)

Anchoring factors are evident in an environment where there is an increase in access to information opportunities of individuals. It is quite difficult to decide in an environment where there is so much information for the investor (Lehrer, 2009). This is the reason why people's anchor arises from uncertainty and lack of knowledge or aversion. If people have insufficient data, they pay attention to the first data to reduce uncertainty (Lin, 2012).

According to Del Missier (2007), investment decisions that are new to the investor tend to slow down the decision since most would anchor their decision on recent observation or believes. Fixing or anchoring on ideas affect the investors when new ideas are in place. Mental anchoring then affects the value of decision making and how investors make a decision. Anchoring has some connection with representativeness as it also reflects that people often focus on recent experience and tend to be more optimistic when the market rises and more pessimistic when the market falls (Waweru et al., 2008).

In addition, investment decision has been associated with financial literacy according to research conducted in Pakistan (Awais et al., 2016). Investment decisions according to the decision theory can be risky, certain, or uncertain. According to Awais et al. (2016), risk intensity can be moderate, maximum, or minimum based on the strategy used in decision making. Based on the review of theories and literature, Await et al. (2016) identified that risky investors had higher investment experience and financial literacy that creates risk tolerance. Experienced investor utilises their risk tolerance since they gain experience from past investment decisions. According to Garang (2016), investment decisions can be affected by the availability of investment analysis, cost of the funds and level of development of the company. He concluded that retirement and saving literacy 
affected investment decisions as well as debt management; therefore, financial literacy had a positive influence on investment decisions.

Poor investment decisions are the root cause of SMEs not achieving their objectives; however, the above argument has shown that this can be controlled by anchoring behaviour and financial literacy. Nevertheless, previous literature indicates that behavioural finance factors on investment decisions do not ascertain the moderating effect of financial literacy (Raveendra et al., 2018). Studies have been done on investment decisions focusing only on anchoring or prospect or herding or overconfidence in Nairobi Security Exchange (Shikuku, 2012). Anchoring has been researched on investment decision by many other researchers (Murithi, 2014; Ishfaq \& Anjum, 2015; Andersson \& Johansson, 2014; Usman, 2018). Murithi (2014) found that the decision-making process is affected by past information and hence anchoring was a significant factor in investment decisions.

However, financial literacy has not been investigated in relation to investment decisions. Those few who concentrated their study on behavioural factors have not investigated financial literacy as a moderating factor (Athur, 2014; Raveendra et al., 2018; Ngoc, 2014; Kremer et al., 2013a; Nyakundi, 2017). There is a need to introduce financial literacy as it suppresses behavioural factors. Financial literacy provides individual knowledge hence increase the scope of making rational investment decisions. Given the significant role played by SMEs in Kenya, it is important to understand anchoring behaviour that influences investment decision as well as ascertain the effect of financial literacy. Therefore, this study sought to establish the effect of anchoring behaviour and financial literacy on investment decisions among small and micro enterprises in Nairobi County, Kenya.

\section{THEORETICAL FRAMEWORK}

The regrets theory was proposed by Bell (1982). The theory speaks of choice of uncertainty considering the effect of anticipated regret. It has been found that individuals prefer options that screen them from discovering the results of forgone choices. The anticipated pain of regret is eliminated if individuals do not know the results of the forgone choice, and thus, the option of not entering a gamble is more attractive if, in the condition of not entering, one will never know if one would have won or lost. This theory states that people anticipate regret if they make a wrong choice and take this anticipation into consideration when making decisions; this theory has been used to explain anchoring and regret aversion biases.

In investing, the fear of regret can make investors either risk-averse or motivate them to take high levels of risk. Therefore, this theory deals with the emotional reaction for investors' experience after realising they have made any errors in their evaluation and then their decision. Faced with the prospect of selling a stock, investors become emotionally affected by the price at which they purchased the stock (Fogel \& Berry, 2006). Therefore, they avoid selling it as a way to avoid the regret of having made a bad investment, as well as the embarrassment of reporting a loss (Pompian, 2011). Regret theory can also hold true for investors who find a stock they had considered buying but did not go up in value. Some investors avoid the possibility of feeling this regret by following the conventional wisdom and buying only stocks that everyone else is buying, rationalising their decision with "everyone else is doing it" (Jagongo and Mutswenje, 2014).

The theory is related to the study since it tries to explain how certain wrong choices made by a manager can affect their future decision making. The managers in SMEs will anchor on the financial crisis they have experienced and, therefore, may not be willing to take the risk. This results in a higher 
level of stress, which can make them under weigh values and obligation in their decision making since they are too much risk and loss averse. Loomes and Sugden (1987) argue that the theory explains and predicts violations of expected utility theory. The theory is applied in behavioural factors since regret is one of the blocking factors in the decision-making process. Most SMEs will consider the risk factors, but if the risk cannot be measured resulting in uncertainty in decision making most management science elites would use the regret-based method in decision making. According to Loomes \& Sugden (1982), regret theory explains rational behaviour when uncertainty exists. Most personal traits and behaviour may violet this rational thinking and affect their decision-making process. Anchoring is another behaviour that would affect if the rational consideration of regret in uncertainty in decision making. Generally, organisations or individuals who use prospect would deploy the regret theory as part of their rational judgement. This will assist in obtaining better decisions with the exception of the basis of prior knowledge of decision making.

\section{REVIEW OF LITERATURE}

\section{Anchoring and Investment Decision Making}

Murithi (2014) investigated the effect of anchoring on investment decision-making by individual investors in Kenya. Murithi (2014) focused on psychological traits based on group or individual portfolio managers, analysts and investors in the decision-making process. Most literature indicates that most institutional and individual heuristics have been used in investment decisions. The findings indicated that anchoring behaviour influenced the decision-making process of an investor in relation to past performance. Anchoring had a strong positive relationship with investment decision making $\left(\mathrm{R}^{2}=0.936\right)$. The study recommended the use of computation skills so as ease decisionmaking in place of heuristics behaviour.
Ishfaq and Anjum (2015) did research on the effect of anchoring bias on risky investment decision. The research was done in Pakistan Equity Market (PEM) to examine the effect of psychology on market inadequacy with the market. Emotions, feelings and cognitive error descript investor's decisions. The researchers wanted to ascertain the impact of prior knowledge on the behaviour of the decision-making process. The study concluded that investors put into consideration anchoring biases as a risk element in their decision-making process in investment portfolios. Hence, there exists a positive relationship between anchoring and risky investment decision.

Jetter and Walker (2016) investigated anchoring in financial decision-making evidence from the field. It analysed 12,596 betting choices of 6,064 competitors in the US game show jeopardy. According to the results, more than half of wagers were within $\$ 500$ of the original dollar value even though the highest possible wagering amounts to $\$ 5,914$. The results further indicated that anchoring was statistically significant on the basis of playerfixed effects, time trends, clue category and control scores. Raising anchoring by 10 percentage showed a rise of 3.1 per cent in the gamble. It was noted that preference and individual behaviour attitude were the anchoring factors. Women used anchoring with the elasticity of 0.34 against their counterpart male with 0.28. There exists little indication for anchoring in children and teenagers. Hence anchoring was found to significantly influence investment decision making.

Kremer et al. (2013b) examined behavioural biases and firm behaviour in Kenyan retail shops. The study established that loss aversion had a significant effect on the investment decision of Kenyan retail shop owners. Kungu (2016) conducted a study on the effect of cognitive biases on individual investment decisions at the Nairobi Securities Exchange. The study sought to establish the cognitive biases which influence individual investment decisions at the Nairobi Securities 
Exchange. Major findings indicated that results of individual investment decisions were significantly correlated to a number of cognitive biases, including; random walk anchoring, excessive optimism and accounting information. The study concluded that cognitive biases play a significant role in individual investment decisions. It indicates that cognitive biases include heuristic characteristic where anchoring is one of them.

Usman (2018) did research on the influence of cognitive biases on investment decision making in the property market in plateau state in Nigeria. The findings indicated that anchoring bias, representative bias, narrow framing and overconfidence affected decision making. The positive coefficient on the variable indicated that experienced investors used personal judgment in making decisions. The research concluded that investors rebalance portfolios at least yearly, determines appropriate asset allocation strategy, identifies their level of risk tolerance, and long-term investment is appropriate for an investment decision. Andersson and Johansson's (2013) research on anchoring bias in strategic business decisions concentrated on biasness in relation to anchoring, such as group thinking, confirmation bias, availability bias, framing and priming. There was no statistical significance on the participants' choice of supplier recommendation though a small sample was used.

Nyakundi (2017) sought to establish the effect of behavioural biases on the ranking of financing decisions by financial managers of firms listed in the Nairobi Securities Exchange. The objectives of the study established the effect of managerial overconfidence, managerial over-optimism, regret aversion, anchoring, mental accounting and conservatism on the ranking of financing decisions by financial managers of firms listed in NSE. The level of personal skills and competence was investigated as a moderating variable. Findings revealed that managers who were predisposed to overconfidence, anchoring and mental accounting biases were more inclined towards debt and equity compared to internal capital, with equity most preferred, followed by debt then internal sources of capital. However, those with over-optimism bias ranked debt highest followed by equity with the lowest ranking for internal capital. On the other hand, managers with a predisposition towards regret aversion and conservatism behavioural biases highly ranked internal capital and debt compared to equity; internal capital was most preferred, followed by debt than equity. Thus, the study hypotheses developed:

\section{$H_{01}$ : There is no significant effect on anchoring behaviour on Investment Decision Making}

\section{Moderating Effect of Financial Literacy}

In order to facilitate a future operationalisation of the concept, these aspects could be grouped into five dimensions: knowledge about financial concepts and products; communication aptitudes concerning financial concepts; ability to use knowledge in order to take the necessary financial decisions; the real use of different financial instruments; people's confidence in their previous financial decisions and actions (Huston, 2010). The first two dimensions belong to the category of comprehension or understanding of financial concepts, while the next three dimensions to the category of real usage in the practice of the previous knowledge. These five dimensions of the financial literacy concept need to be operationalised in order to be measured; the operationalisation process transforms conceptual definitions into operational or measurable ones (Zait \& Bertea, 2015).

LAl-Tamimi and Kalli (2009) assessed the financial literacy of the UAE individual investors who invest in the financial markets of the UAE. They found that the financial literacy of UAE investors is much less than what is actually needed. Their results also suggest that there exists a significant relationship between financial literacy and investment decisions. 
Bhushan and Medury (2013) assessed the financial literacy level of salaried individuals in India. They found that financial literacy level gets affected by gender, education, income, nature of employment and place of work, whereas it does not get affected by age and geographic region. For a long time, researchers have researched the demographic factors that influence the investment decisions of an individual. The focus has mostly remained on core factors such as age, gender, income, marital status, professions, education and financial knowledge. A number of research studies have been undertaken in India and abroad to identify the investment behaviour of retail investors and households.

Geetha and Ramesh (2011) studied the Indian's behaviour about investment preferences. The study found that people were not aware of all the investment options available to them, and they lacked knowledge about securities. Samudra and Burghate (2012) studied the investment behaviour of middle-class households in Nagpur. Bank deposits were found to be the most popular instrument of investment, followed by insurance. Small savings schemes such as PPF, Post office savings deposits are the third preferred investment option. Return from investment ranks first amongst the factors which influence the decision to invest in a particular institution.

Investment decision in Malaysia and the United Kingdom indicates that businesses are highly affected by the type of investment, financial literacy and risk tolerance (Janor et al., 2016). In Malaysia, it was identified that the financial literacy level was low and the government had to increase financial awareness. Financial literacy was found to affect the investor's behaviour in decision making. There exists a gap in financial literacy in Malaysia as compared to the United Kingdom.

Kengatharan and Kengatharan (2014) alluded that the investment decision is influenced by behavioural factors based on research in Sri Lanka. Market, prospect, heuristics and herding had a significant effect with anchoring leading on investment decision; hence, the choice of stock made was negatively affected by herding, just like overconfidence. Anchoring was positively affected by investment performance. From this finding, some behavioural factors contribute positively and others negatively.

Garang (2016) conducted research in South Sudan that shows that investment decision consists of choices made in finance that can be assigned to a specific asset for income generation. A study conducted in Nigeria investigating the impact of investment decision was investigated using a theoretical perspective in relation to financial literacy. The assessment of decision theory, the theory of mental accounting and prospect theory showed the relationship between financial literacy and investment decision making (Akims \& Jagongo, 2017). In conclusion, the theoretical aspect of the financial literacy of an investor or manager had a positive influence on their decision.

Mugo (2016) conducted research on the investment decision that showed that financial literacy was a factor affected by both financial behaviour and financial awareness. According to the research, SACCOs should advance their financial management attitude and skills so as to better investment decisions. Therefore, financial awareness and behaviour have no significant effect on investment decision. In a study conducted in Kisumu, Kenya, investment decisions can be affected by behavioural factors such as overconfidence, anchoring bias, herd behaviour, risk aversion, representative bias and mental accounting (Ojwang, 2015). Behavioural biasness, according to Ojwang (2015), could be improved through training and hence improve investment decision making. Amisi (2012) investigated the effect of financial literacy on investment decision making by pension fund managers in Kenya. The study revealed financial literacy and investment decisions have a significant relationship. The study 
concluded that financial literacy positively influences investment decision making.

Bhushan (2014) examined the connection between financial literacy and investment behaviour of the individuals who receive monthly payments from both the government and non-government jobs in Himachal Pradesh, India. By use of five hundred and sixteen questionnaires, data were collected using a combination of multi-stage and purposive techniques sampling as the target population was wide. Financial literacy was assessed in three dimensions of financial attitude, behaviour, knowledge and awareness, where the 5-Likert scale was applied. Bhushan concluded that high levels of financial literacy created more financial awareness of the financial products hence were found to be likely to make wiser investment decisions as compared to their counterpart with low financial literacy. Those with low financial literacy are usually constrained in terms of the choice of where to invest and therefore opt to invest in limited traditional products. Though traditional products are considered safer and to yield more return, they carry riskier. Bhushan argues that it is a must to have at least a certain level of financial literacy to understand risk and return concepts as well as choose financial products correctly.

$H_{01}$ : Moderating Effect of Financial Literacy on Relationship between Anchoring and Investment Decision among SMEs in Nairobi County

\section{MATERIAL AND METHOD}

The study adopted a positivist paradigm; this paradigm was selected since the study employed quantitative data. The study used an explanatory research design to assess and establish the effect of behavioural factors on SME investment decisions in Nairobi County. A target population of 102,821 registered SMEs within Nairobi County were considered (Nairobi County, Ministry of Trade, 2016). Managers were selected purposively on the grounds that they are in a superior position to comprehend investment decision issues of SMEs and in a position to give the correct data. Random sampling was used to select the 383 SMEs that participated in the study. The study used questionnaires to collect primary data. Closedended questions were used in the questionnaire to measure the variable, providing all-around information about the variables. The study variables were based on previous studies and a detailed review of existing literature. In line with the measurement used in previous studies, a five-point Likert scale was adopted for all item scale ranging from $1=$ strongly disagree to $5=$ strongly agree and $1=$ very low to $5=$ very high. The researcher opted for this scale to create a 'neutral' middle point which is essential in some scales where respondents may simply not have an opinion (Chuong \& Ooi, 2008).

\section{Dependent and Independent Variables}

Investment Decision was measured using a proxy of 1 item on a five-point Likert scale (ordinal level) adopted and modified from Nyakundi (2017); Omery (2014); Awais et al. (2016); Kengatharaan and Kengatharaan (2014); Garang (2016); Ojwang (2015). Anchoring factors were the independent variables. These factors were measured using five items as indicated by Murithi (2014), Ishfaq and Anjum (2015), Andersson \& Johansson (2013). The moderating variable was financial literacy. Financial literacy was a proxy of 8 items on a fivepoint Likert scale (ordinal level) adopted and modified from Garang (2016), Chaturvedi \& Khare (2012), Sood \& Medury (2012).

Reviewed literature demonstrates constructs testing for reliability accomplished by ascertaining the Cronbach's alpha coefficient. Every one of the constructs was found to had a sufficient alpha value (> 0.6) (Hair et al., 1998). The constructs testing for reliability was accomplished by computing the Cronbach's alpha which was 0.834 . In this study, construct validity was assured by deriving investment behaviour from existing literature. Table 
1 shows that the factor loadings for most of the variables items were above 0.5 . The factors accounted for above $50 \%$ of the total variance. The Kaiser-Meyer-Olkin measure value (0.616) was above 0.5 hence acceptable. Also, Bartlett's Test

Table 1: Reliability and Validity Analysis was significant. Davis (1964) suggests 0.5 as the minimum reliability coefficient. while Sekeran (2003) posits that any values between 0.5 and 0.8 are adequate to accept internal consistency.

\begin{tabular}{|c|c|c|c|c|}
\hline & loadings & KMO & TVE/CV & $\begin{array}{l}\text { Bartlett's } \\
\text { Test }(\chi 2)\end{array}$ \\
\hline Investment decision $($ Cronbach's Alpha $=.711)$ & & 0.616 & 45.95 & $283.737 *$ \\
\hline $\begin{array}{l}\text { SME has increased the amount to be invested asset } \\
\text { category }\end{array}$ & 0.548 & & & \\
\hline $\begin{array}{l}\text { SME has been able to open many branches in other } \\
\text { parts of the country }\end{array}$ & 0.779 & & & \\
\hline $\begin{array}{l}\text { SME has been able to diversify its business in other } \\
\text { sectors }\end{array}$ & 0.77 & & & \\
\hline $\begin{array}{l}\text { The SME able to borrow more loans which have } \\
\text { increased its business stock }\end{array}$ & 0.585 & & & \\
\hline $\begin{array}{l}\text { SME decision-making helps the enterprise to achieve its } \\
\text { investment objectives }\end{array}$ & 0.724 & & & \\
\hline $\begin{array}{l}\text { In general, the SME satisfied with the way of making } \\
\text { investment decisions }\end{array}$ & 0.515 & & & \\
\hline $\begin{array}{l}\text { SME investments decisions can mostly earn higher than } \\
\text { average return in the market }\end{array}$ & 0.679 & & & \\
\hline SME make all investment decisions on their own & 0.637 & & & \\
\hline Anchoring Factors (Cronbach's Alpha =.705) & & 0.705 & 64.088 & $278.893 *$ \\
\hline $\begin{array}{l}\text { Most decision-making processes involve the use of } \\
\text { information collected }\end{array}$ & 0.684 & & & \\
\hline $\begin{array}{l}\text { Prejudge prices are mostly found to be lower than the } \\
\text { initial price. }\end{array}$ & 0.797 & & & \\
\hline $\begin{array}{l}\text { Decision making is sensitive to business information } \\
\text { available as experienced in the past. }\end{array}$ & 0.771 & & & \\
\hline It takes time to purchase new products in the market & 0.833 & & & \\
\hline $\begin{array}{l}\text { Past experience with the business affect purchase } \\
\text { decisions }\end{array}$ & 0.839 & & & \\
\hline Financial Literacy $($ Cronbach's Alpha = .716) & & 0.708 & 52.819 & $580.215^{*}$ \\
\hline $\begin{array}{l}\text { The SMEs gathers data and analyse the current financial } \\
\text { situation before making a financial decision }\end{array}$ & 0.762 & & & \\
\hline $\begin{array}{l}\text { The entrepreneur executes a plan with the help of } \\
\text { experts, i.e. financial planner, insurance advisor, etc. }\end{array}$ & 0.77 & & & \\
\hline $\begin{array}{l}\text { The SMEs review the financial plan periodically after } \\
\text { implementation }\end{array}$ & 0.744 & & & \\
\hline $\begin{array}{l}\text { The entrepreneur has knowledge of financial } \\
\text { management }\end{array}$ & 0.627 & & & \\
\hline $\begin{array}{l}\text { Well conversant when it comes to matters relating to } \\
\text { financial issues }\end{array}$ & 0.728 & & & \\
\hline $\begin{array}{l}\text { There is confidence in making financial or saving } \\
\text { decisions }\end{array}$ & 0.728 & & & \\
\hline The entrepreneur understanding of financial planning & 0.588 & & & \\
\hline
\end{tabular}




\section{loadings $\quad$ KMO $\quad$ TVE/CV Bartlett's Test ( $\chi 2)$}

The SMEs sets financial goals and objectives for my

0.521

business

Extraction Method: Principal Component Analysis.

Rotation Method: Varimax with Kaiser Normalization.

\section{Analytic Model}

Further, the study employed inferential statistics in the form of multiple regression and Pearson correlation analysis. Linear regressions were appropriate for the study because there is more than one independent variable involved in the analysis and establishing whether relationships between variables are significant by testing hypothesis (Zikmund et al., 2010). Thus, it sought to establish the moderating effects using the hierarchical regression model. The hypotheses were tested using the moderated regression analysis to establish the extent to which the moderator variable affects the relationship. The moderator effect was examined using regression analysis procedures as outlined by Aiken and West (1991).

$Y=\beta_{0}+\beta_{1} \mathrm{FA}+\beta_{2} \mathrm{FS}+\varepsilon \ldots \ldots \ldots \ldots \ldots \ldots \ldots 1$

$Y=\beta_{0}+\beta_{1} \mathrm{FA}+\beta_{2} \mathrm{FS}+\beta_{3}$ Anch $+\varepsilon \ldots \ldots . .2$

$Y=\beta_{0}+\beta_{1} \mathrm{FA}+\beta_{2} \mathrm{FS}+\beta_{3}$ Anch $+\beta_{4} \mathrm{FL}+$

E.......................................... 3

$Y=\beta_{0}+\beta_{1} \mathrm{FA}+\beta_{2} \mathrm{FS}+\beta_{3}$ Anch $+\beta_{4} \mathrm{FL}+$ $\beta_{5}$ Anch $*$ FL $++\varepsilon \ldots \ldots \ldots \ldots \ldots \ldots \ldots \ldots \ldots \ldots . .4$

Where: InvDec- Investment Decision; FA- Firm Age; FS-Firm size; Anch- Anchoring; FL financial literacy; $\beta_{0}$-is a constant; $\varepsilon$-is Error term (unexplained variation due to other unmeasured factors).

\section{RESULTS AND DISCUSSION}

This section provides a presentation of research findings collected through the methodology discussed in chapter three. A total of 383 questionnaires were given to SMEs within Nairobi.
After data collection and screen completely filled questionnaires were 375, which represent $97.9 \%$ about 5 questionnaires were scantly answered and could not be used in data analysis which was not included in the 375 completed questionnaires, remaining with 370 . In addition, the study deducted 4 cases from 366 cases (95.6\%). According to Mugenda and Mugenda (1999), a threshold of $80 \%$ and above is sufficient enough to continue with the research. The response rate was 375(97.9\%), which was above the threshold of $80 \%$. This was deemed ideal for the study basing on recommendations of a response rate in the range of $50 \%$ and $70 \%$ (Saldivar, 2012).

\section{Sample Characteristics}

Table 2 indicated that the majority of SMEs firm were micro in size, with 314 respondents representing $85.8 \%$, while Small firm size was 52 respondents representing $14.2 \%$ of total respondents. There were six times as many Micro as were Small size firms. The experience of the respondents was evaluated in Table 2, where the majority of 207 respondents representing $56.6 \%$ of the total respondents, have worked in the enterprise for 5-9 years. It was followed closely by less than 4 years, with 99 respondents representing $27 \%$, then 10-14 years, with 48 respondents representing $13.1 \%$ and finally above 15 years representing $3.3 \%$ of the respondents. Table 2 reveals that the education level had 21 respondents representing $5.7 \%$ who had a secondary level of education and below. The majority of entrepreneurs had diplomas with 191(52.2\%) respondents; the undergraduate degree was $130(35.5 \%)$ respondents, while postgraduate was $24(6.6 \%)$ respondents. Since the majority of the entrepreneurs possess high levels of education, they are likely to capitalise on financial 
East African Journal of Business and Economics, Volume 3, Issue 1, 2021

Article DOI: https://doi.org/10.37284/eajbe.3.1.305

publications while making investment decisions as opposed to seeking advice from family members, friends and brokers. Finally, Table 2 indicated that
359(98.1\%) respondents were Kenyans, while $7(1.9 \%)$ respondents were foreigners. Kenyan owners represented the majority of business owners.

Table 2: Demographic Information of Respondents

\begin{tabular}{llll}
\hline Factors & & Frequency & Per cent \\
\hline Firm Size & Micro & 314 & 85.8 \\
& Small & 52 & 14.2 \\
& Total & $\mathbf{3 6 6}$ & $\mathbf{1 0 0}$ \\
\hline Experience & Less than 4 yrs & 99 & 27 \\
& $5-9$ yrs & 207 & 56.6 \\
& $10-14$ yrs & 48 & 13.1 \\
& Above 15 yrs & 12 & 3.3 \\
& Total & $\mathbf{3 6 6}$ & $\mathbf{1 0 0}$ \\
\hline Education & Secondary and below & 21 & 5.7 \\
& Diploma & 191 & 52.2 \\
& Undergraduate Degree & 130 & 35.5 \\
& Postgraduate & 24 & 6.6 \\
& Total & $\mathbf{3 6 6}$ & $\mathbf{1 0 0}$ \\
\hline Origin of Business & Kenyan & 359 & 98.1 \\
& Foreign & 7 & 1.9 \\
& Total & $\mathbf{3 6 6}$ & $\mathbf{1 0 0}$ \\
\hline
\end{tabular}

\section{Multivariate Analysis}

From the findings, financial literacy had the highest mean (4.12), followed by anchoring factors (3.88), while investment decision had the lowest mean (mean $=3.82$ ). The implication is that entrepreneurs have high levels of financial literacy and are less overconfident in their investment decisions. The standard deviations for all the variables except prospect factors were less than 1, indicating fewer variations in the responses. Finally, all independent variables and the dependent variable were normally distributed, as shown in Table 3 below. Table 3 highlights the findings on the correlation between anchoring, financial literacy and investment decision. The results revealed that anchoring factors has significant positive relationship with investment decision, $(r=.681, \rho \leq .05)$. There exist significant positive relationship with investment decision $(r=$ .713, $\rho \leq .05$ ). Similarly, there existed positive significant relationship between anchoring and financial literacy $(\mathrm{R}=.587, \rho \leq .05)$.

Table 3: Multivariate Analysis

\begin{tabular}{llllllll}
\hline & $\mathbf{1}$ & $\mathbf{2}$ & $\mathbf{3}$ & $\mathbf{4}$ & $\mathbf{5}$ & $\mathbf{6}$ & $\mathbf{7}$ \\
\hline 1 & 1 & & & & & \\
2 & $.681^{* *}$ & 1 & & & & & \\
3 & $.713^{* *}$ & $.587^{* *}$ & 1 & & & & \\
4 & $.149^{* *}$ & 0.032 & $.133^{*}$ & 1 & & & \\
5 & 0.082 & 0.075 & $.128^{*}$ & $.440^{* *}$ & 1 & & \\
6 & -0.002 & -0.012 & 0.095 & $.386^{* *}$ & $.828^{* *}$ & 1 & \\
7 & 0.062 & 0.053 & $.163^{* *}$ & $.332^{* *}$ & $.641^{* *}$ & $.610^{* *}$ & 1 \\
\hline$* *$ Correlation is significant at the 0.01 level (2-tailed). & & & \\
$*$ Correlation is significant at the 0.05 level (2-tailed).
\end{tabular}


East African Journal of Business and Economics, Volume 3, Issue 1, 2021

Article DOI: https://doi.org/10.37284/eajbe.3.1.305

1 - investment Decision; 2 -Anchoring Factors; 3 - Financial Literacy; 4 -Firm Size; 5 - Business Age; 6 - Experience; 7 - Education

\section{Multivariate Analysis}

These hypotheses $\left(\mathrm{H}_{01}\right.$ and $\left.\mathrm{H}_{02}\right)$ were tested using hierarchical regression. Prior to conducting hierarchical regression analyses, all study variables were standardised as z-scores to test for interaction terms (Aiken \& West, 1991). Z-standardization of the variables allows easy interpretation of the interaction effects (Dawson, 2014). Table 4 further illustrates the model summary of the regression model; the results showed that all the predictors explained 62 per cent variation of investment decision. This showed that considering the study variables of independent variables; there is a probability of predicting investment decisions by $62 \%$ ( $\mathrm{R}$ squared $=0.62)$. Finally, study findings in the table indicated that the above-discussed coefficient of determination was significant as evidence of $F$ ratio change of 141.26 with a p-value $0.000<0.05$ (level of significance). Thus, the model was fit to predict investment decision using anchoring factors
$\mathbf{H}_{01}$ stated that anchoring has no significant effect on investment decisions among SMEs in Nairobi County. However, research findings showed that anchoring had coefficients of the estimate, which was significant basing on $\beta_{1}=0.12$ ( $p$-value $=$ 0.001 , which was less than $\alpha=0.05$ ); hence the null hypothesis was rejected. This indicated that for each unit increase in anchoring among the entrepreneurs, there was a 0.12 units increase in investment decisions among SMEs in Nairobi County.

$\mathbf{H}_{02}$ specified that financial literacy moderates the relationship between anchoring factors and investment decisions $(\beta=.92, \rho<.05)$. So, the null hypothesis was rejected. This was also confirmed by $\mathrm{R}^{2} \Delta$ of .07, which indicates that financial literacy moderates the relationship between anchoring factors and investment decision by $7 \%$. This implies that financial literacy enhances the relationship between anchoring factors and investment decisions.

Table 3: Hierarchical regression model for a Moderation effect

\begin{tabular}{llll}
\hline & Model 1 & Model 2 & Model 4 \\
& $\mathrm{B}(\mathrm{se})$ & $\mathrm{B}(\mathrm{s.e})$ & $\mathrm{B}(\mathrm{se})$ \\
\hline (Constant) & $(-0.05(.05)$ & $(-0.05(.03)$ & $(-0.01(.03)$ \\
Zscore:FS & $0.15(.06)^{*}$ & $0.11(.04)^{* *}$ & $0.09(.03)^{*}$ \\
Zscore:BA & $0.13(.01)$ & $(-0.01(.07)$ & $0.04(.06)$ \\
Zscore: Exp. & $(-0.17(.01)$ & $(-0.06(.06)$ & $(-0.06(.06)$ \\
Zscore: Edu. & $0.05(.07)$ & $0.00(.05)$ & $(-0.04(.04)$ \\
Zscore:OB & $0.09(.05)$ & $0.05(.03)$ & $0.04(.03)$ \\
Zscore: Overco. & & $0.07(.05)$ & $\left(-0.55(.08)^{* *}\right.$ \\
Zscore:AF & & $0.12(.06)$ & $0.15(.05)^{* *}$ \\
Zscore(AF*FL) & & & $0.92(.01)^{* *}$ \\
Model Summary & 1 & 2 & 4 \\
R & 0.21 & 0.79 & 0.85 \\
R Square & 0.04 & 0.63 & 0.72 \\
Adjusted R Square & 0.03 & 0.62 & 0.71 \\
Std. Error of the Estimate & 1.03 & 0.64 & 0.56 \\
Change Statistics & & & \\
R Square Change & 0.04 & 0.59 & 0.07 \\
F Change & 3.28 & 141.26 & 93.08 \\
df1 & 5 & 4 & 1
\end{tabular}




\begin{tabular}{llll}
\hline & Model 1 & Model 2 & Model 4 \\
& B(se) & B(s.e) & B(se) \\
\hline df2 & 360 & 356 & 354 \\
Sig. F Change & 0.01 & 0.00 & 0.00 \\
\hline
\end{tabular}

Dependent Variable: Zscore: Investment Decision $* * p<.01,{ }^{*} p .05 ; F S=$ Firm Size, BA= business age, Exp $=$ experience, $O B=$ Origin of Business, $A F=$ Anchoring Factor, $F L=$ financial literacy

\section{Graphical Representation of the Moderating} Effect of Financial Literacy

The interaction plot in Figure 1 displays an enhancing effect that as financial literacy increases as well, as depicted by the steepness of the slope. Model 4 was used to test the effect of financial literacy on the relationship between anchoring factors and investment decisions. The results indicated that both control variables were not significant in the model. The model found that financial literacy has a significant moderating effect on anchoring factors. The corresponding interaction of financial literacy was $\beta=.92 \rho<.05$ on investment decision. This implies that financial literacy moderates' the relationship between anchoring and investment decision; hence this hypothesis is rejected. The results indicated $R^{2}=$ $.72, \Delta R^{2}=.07$ found financial literacy contributed $7 \%$ of the variation in investment decision. The null hypothesis of $\mathrm{H}_{02}$ was rejected.

Figure 1: Moderating Effect of Financial Literacy on Anchoring Factors and Investment Decisions

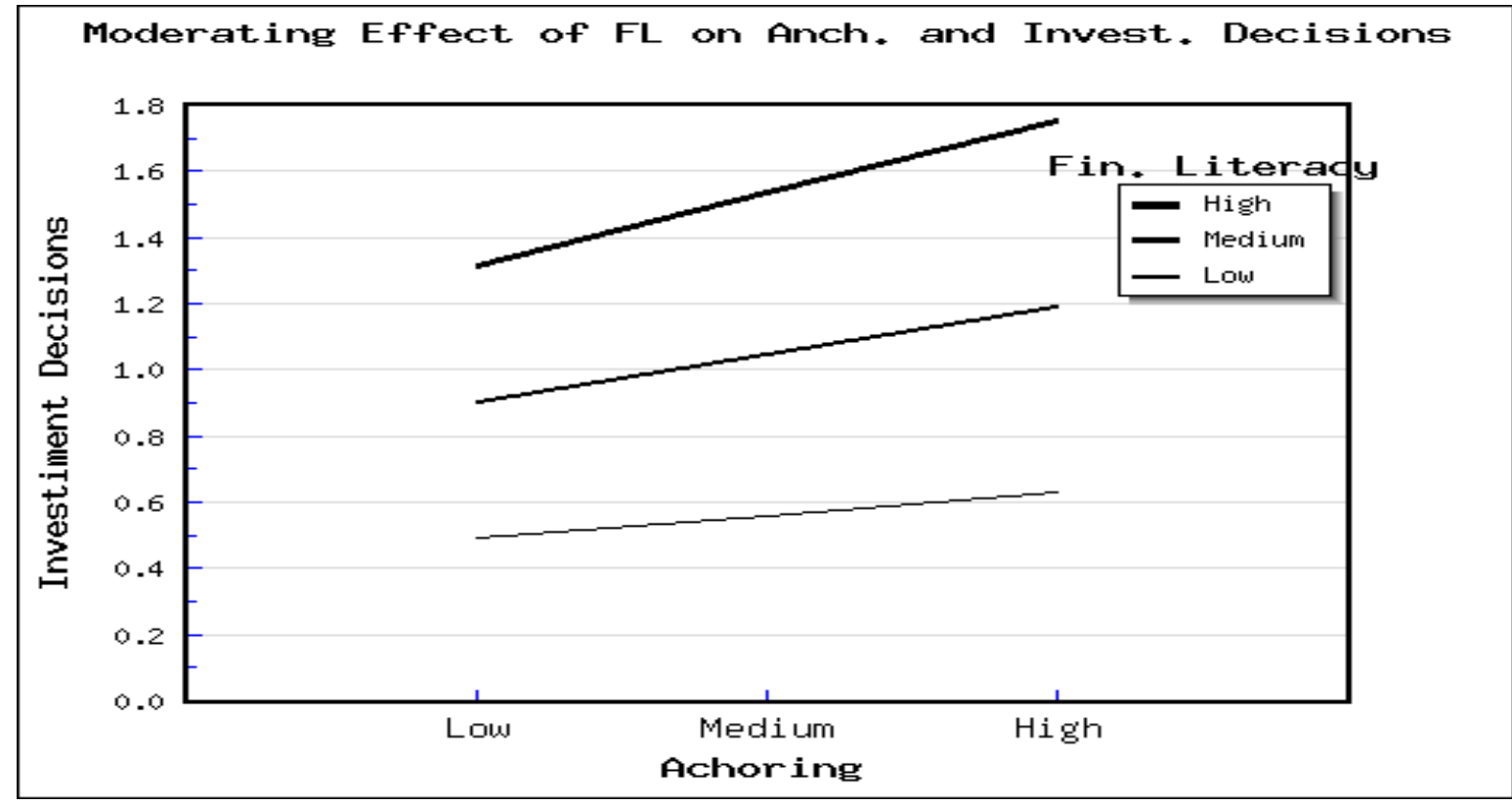

\section{DISCUSSION}

On anchoring factors, most decision-making process involves the use of information collected. In fact, past experience with the business affects purchase decisions. Also, it takes time to purchase new products in the market. As well, decision making is sensitive to business information available as experienced in the past. Furthermore, prejudge prices are mostly found to be lower than the initial price. The regression results indicated that anchoring factors had a positive and significant effect on investment decisions among the SMEs in Nairobi County. Consequently, the null hypothesis was rejected, and the alternative accepted, which was anchoring, has a significant effect on 
investment decisions among SMEs in Nairobi County. Furthermore, financial literacy positively and significantly moderates the relationship between anchoring and investment decisions among SMEs. Therefore, the null hypothesis was rejected, and the alternate hypothesis was accepted, which was that financial literacy does moderate the relationship between anchoring and investment decisions among SMEs in Nairobi County.

The finding indicated that the anchoring factor had a significant positive influence on investment decisions. Anchoring was similarly found to have a strong significant relationship with investment decisions by Murithi (2014). The findings indicate that investors related investment decisions with past performance, which was also found to be key in the current research where information from past records assisted the majority of SMEs to make investment decisions. The results were also in line with Ishfaq and Anjum (2015), who found that anchoring had a positive relationship with investment decisions. However, Ishfaq and Anjum (2015) focused on risk investment portfolio as the basis of decision making.

The findings also concurred with Jetter and Walker (2016) even though the results focused on playerfixed effects, time trends, clue category and control scores. Preference and individual attitude were the main indicators of anchoring factors in Jetter and Walker (2016); the current study focuses on past experience and utilisation of available information. Experience and use of information in the decisionmaking process mean that it plays an improvement in investment decisions. Similarly, Kremer et al. (2013) also found that the behavioural factors significantly affected a firm's investment decision.

On the contrary, Anderson and Johansson (2013) found that anchoring biasness as a result of group thinking, confirmation bias, availability bias, framing and priming had no significant effect on investment decisions. The results were also criticised based on their small sample size, unlike the current study. Therefore, anchoring has a significant positive effect on investment decisions.

Financial literacy does moderate the relationship between anchoring and investment decisions among SMEs in Nairobi County. In fact, with the incorporation of financial literacy, entrepreneurs have the capability of establishing the type of anchor that is likely to influence the investment decision. Also, with financial literacy skills, the entrepreneurs are capable of being open to new information and less conservative. Consequently, financial literacy is key to enhancing investment decisions (Nga et al., 2010; Geetha \& Ramesh, 2011).

\section{CONCLUSION}

The study concluded that firm size had a significant positive effect on investment decision. Larger firms made better investment decisions than their small counterparts. Age had no significant effect on investment, whereby investment decision does depend on the experience.

In addition, anchoring has a positive influence on investment decisions among SMEs in Nairobi County. The implication is that the entrepreneurs are susceptible to anchoring since they majorly rely on past experience, past prices (fair prices) and ignore new information. The relationship between anchoring and investment decision is further enhanced when moderated with financial literacy.

The interactive effect of financial literacy was found to affect positively anchoring and improved investment decisions. It implies that financial literacy assists in enabling the investors to gain knowledge on how to invest in risker investment to improve decisions made in the firms. Anchoring and prospect results indicated that it had a positive effect on investment decisions. The results support the regret theory since it is based on rational consideration of regret in uncertainty in decision making. The introduction of financial literacy showed that it reduces the positive on anchoring and 
negatively on the prospect of investment decision. This indicates that financial literacy improves on rational decision making reduce improving investment decision.

\section{Theoretical Implications}

Prospect theory is highly linked with prospect factors, where the findings showed that prospect factors had a significant effect on investment decisions. Despite financial literacy not affecting the interactive effect on prospect factors. The study strongly related the theory to investment decisions and showed that people frame and value a decision involving uncertainty, and therefore, they look at choices in terms of potential gains or losses in relation to a specific reference point, which is often the purchase price. Competency theory explains the need for financial literacy. The results indicated that with the introduction of financial literacy, the investment decision was improved, which further improved interaction with behavioural factors. This explains the need to improve financial skills, knowledge and awareness in firms. Finance literacy affected overconfidence and herding factor positively on investment decision but negatively affect anchoring on investment decision, despite not affecting investment decision on interaction with prospect factors.

\section{RECOMMENDATION}

Regarding anchoring, entrepreneurs should establish the type of anchor that is likely to influence their investment decisions making. Particularly, they need to consult widely before making decisions in order to overcome the anchoring bias. They should also follow objective investment strategies and adjust their predictions enough to reflect new information. Moreover, they should not be conservative to the initial reference point but be open to new information.

\section{Recommendation of Further Studies}

The study investigated the effect of behavioural factors and financial literacy on investment decisions among small and micro enterprises in Nairobi County. The scope of this study was limited to the collection of primary data; there is, therefore, the need to use secondary data to undertake the same study in order to detect variations and similarities in the findings. Secondary data is easily available, and less time will be spent investigating behavioural factors that influence investment decisions. Secondary data provides a wider database of data for analysis, to the extent that cannot be achieved when using primary data. In addition, other analytical models other than regression analysis can be employed to study the relationship between individual investment decisions and behavioural finance factors, such as structural equation modelling.

\section{LIMITATION}

The study is limited to the business that is within Nairobi County and hence does not represent green economy and blue economy concepts in other regions where farming and fishing are the main economic activities. Hence there is room for green financial and financial literacy on investment decisions.

\section{ACKNOWLEDGEMENT}

This publication was supported by Bomet University College's research fund award the number 000006 for the attainment of my $\mathrm{PhD}$ and scholarly research towards being a multidisciplinary institution of quality and innovative research for sustainable development and social transformation for the advancement of humanity. 


\section{REFERENCES}

Aiken, L. S., \& West, S. G. (1991). Multiple regression: Testing and interpreting interactions. Sage Publications, Inc.

Akims, M. A., \& Jagongo, A. (2017). Financial Literacy And Its Impact On Investment Decisions In Nigeria: A theoretical perspective. International Journal of Scientific Research and Innovative Technology, 4(11), 1830.

Akintoye, R. I., \& Olowolaju, P. S. (2008). Optimising Macroeconomic Investment Decisions: ALesson from Nigeria. European Journal of Scientific Research, 22(4), 469-479.

Al-Tamimi, H. A. H. \& Bin Kalli, A. A. (2009). Financial literacy and investment decisions of UAE investors. The Journal of Risk Finance, 10(5), 500-516.

Amisi, S. (2012). The effect of financial literacy on investment decision making by pension fund managers in Kenya. Master's Thesis, University of Nairobi.

Andersson, S., \& Johansson, S. (2014). Anchoring bias in strategic business decisions. Gothenburg University.

Athur, A. D. (2014). Effect of behavioural biases on investment decisions of individual investors in Kenya. Master's Thesis, University of Nairobi.

Awais, M., Laber, M. F., Rasheed, N., \& Khursheed, A. (2016). Impact of financial literacy and investment experience on risk tolerance and investment decisions: empirical evidence from Pakistan. International Journal of Economics and Financial Issues, 6(1), 73-79

Bell, D. E. (1982). Regret in decision making under uncertainty. Operations research, 30(5), 961981.
Bhushan, P. (2014). Relationship between Financial Literacy and Investment Behavior of salaried Individuals. Journal of Business Management \& Social Sciences Research, 3(5), 82-87.

Bhushan, P., \& Medury, Y. (2013).Financial literacy and its determinants. International Journal of Engineering, Business and Enterprise Applications, 4(2), 155-160

Chaturvedi, M., \&Khare, S. (2012). Study of saving pattern and investment preferences of individual households in India. International Journal of Research in Commerce and Management, 3(5), 115120

Chong, A. \& Ooi, K. (2008). Adoption of interorganisational system standards in supply chains: an empirical analysis of RosettaNet standards. Industrial Management and Data Systems, 198, 529-47.

Davis, F. B. (1964). Educational measurements and their interpretation. Wadsworth Publishing Company.

Dawson, J. F. (2014). Moderation in management research: What, why, when, and how. Journal of business and psychology, 29(1), 1-19.

Del Missier, F., Ferrante, D., \& Costantini, E. (2007). Focusing effects on predecisional information acquisition. Acta Psychologica, 125(2), 155-174.

Fogel, S. O. C., \& Berry, T. (2006). The disposition effect and individual investor decisions: the roles of regret and counterfactual alternatives. Journal of Behavioural Finance, 7(2), 107-116

Garang, M. (2016). The effect of financial literacy on investment decisions in the Juba City South Sudan. Master's Thesis, University of Nairobi.

Geetha, N., \& Ramesh, M. (2011). A study on people's preferences in Investment Behaviour. International Journal of 
Engineering and Management Research, 1(6), 285-306.

Hair, F., Black, B., Babin, B., Andersion, R. E., \&Tatham, R. L. (1998). Multivariate data analysis. Prentice-Hall, International, Inc

Huston, S. J. (2010). Measuring financial literacy. Journal of consumer affairs, 44(2), 296-316.

Ishfaq, M., \& Anjum, N. (2015). Effect of anchoring bias on risky investment decision. Evidence from Pakistan equity market. International Journal of Engineering and Management Research (IJEMR), 5(4), 32-38.

Jagongo, A., \& Mutswenje, V. S. (2014). A survey of the factors influencing investment decisions: the case of individual investors at the NSE. International Journal of Humanities and Social Science, 4(4), 92-102.

Janor, H., Yakob, R., Hashim, N. A., Zanariah, Z., \& Wel, C. A. C. (2017). Financial literacy and investment decisions in Malaysia and United Kingdom: A comparative analysis. GeografiaMalaysian Journal of Society and Space, 12(2), 106-118.

Jetter, M., \& Walker, J. K. (2016). The effect of media coverage on mass shootings. IZA Discussion Paper No. 11900. Bonn: IZA Institute of Labor Economics.

Kengatharan, L., \& Kengatharan, N. (2014). The influence of behavioral factors in making investment decisions and performance: Study on investors of Colombo Stock Exchange, Sri Lanka. Asian Journal of Finance \& Accounting, 6(1), 1-23.

Kremer, M., Lee, J., Robinson, J., \& Rostapshova, O. (2013b). Behavioral biases and firm behavior: Evidence from Kenyan retail shops. American Economic Review, 103(3), 362-68.
Kremer, S., Bick, A., \& Nautz, D. (2013a). Inflation and growth: new evidence from a dynamic panel threshold analysis. Empirical Economics, 44(2), 861-878.

Kungu, B. W. (2016). The effect of cognitive biases on individual investment decisions at the Nairobi Securities Exchange. Master's Thesis, University of Nairobi.

Lehrer, J. (2009). How We Decide. Boston: Houghton Mifflin Harcourt Publishing Company

Levasseur, C. (2002). Business Value of IT- Nonperformance Measurements (International Edition ed.). London: Oxford Printing Press.

Lin, H. W. (2012). How herding bias could be derived from individual investor types and risk tolerance? International Journal of Economics and Management Engineering, 6(6), 1395-1400.

Loomes, G., \& Sugden, R. (1982). Regret theory: An alternative theory of rational choice under uncertainty. The economic journal,92(368), 805-824.

Loomes, G., \& Sugden, R. (1987). Testing for regret and disappointment in choice under uncertainty. The Economic Journal,97, 118129.

Mugenda, O. M \& Mugenda, A. G. (1999). Research Methods: Quantitative and qualitative Approaches. Nairobi. Acts press. Revised 2003

Mugo, E. (2016). Effect of financial literacy on investment decisions among savings and credit co-operative societies members in Nairobi. Master' Thesis, KCA University.

Murithi, D. K. (2014). The effect of anchoring on investment decision making by individual investors in Kenya. Master's Thesis, University of Nairobi. 
Nga, J. K., Yong, L. H., \& Sellappan, R. D. (2010). A study of financial awareness among youths. Young Consumers, 11(4),277-290.

Ngoc, L. T. B. (2014). Behavior pattern of individual investors in stock market. International Journal of Business and Management, 9(1), 1-16.

Nyakundi, J. B. (2017). Effect of behavioral biases on ranking of financing decisions by financial managers of firms listed in the Nairobi Securities Exchange. Doctoral Thesis, United States International University-Africa.

Ojwang, P. O. (2015). Behavioral Factors and Investment Decisions by Traders in Kibuye Market, Kisumu Town, Kenya. Unpublished report, University Of Nairobi.

Omery, C. S. (2014). The effect of behavioral factors on individual investor choices at the Nairobi securities exchange. Master's Thesis, University of Nairobi

Pompian, M. M. (2011). Behavioral finance and wealth management: how to build investment strategies that account for investor biases (Vol. 667). John Wiley \& Sons.

Raveendra, P. V., Singh, J. E., Singh, P., \& Kumar, S. S. (2018). Behavioral Finance and Its Impact on Poor Financial Performance of SMEs: A Review. International Journal of Mechanical Engineering and Technology, 9(5), 341-348.

Saldivar, M.G. (2012). A Primer on Survey Response Rate. Learning Systems InstituteFlorida State University

Samudra, A., \& Burghate, M. A. (2012). A Study on investment behaviour of middle-class households in Nagpur. International Journal of Social Sciences and Interdisciplinary Research, 1(5), 43-54.
Schwab, K. (2017). The Fourth Industrial Revolution: what it means, how to respond. World Economic Forum.

Sekaran, U. (2003). Research Methods for Business a Skill-Building Approach. 4th Edition, John Wiley and Sons, Hoboken

Shikuku, R. M. (2012). The effects of behavioural factors on investment decision making by unit trust companies in Kenya. Master's Thesis, University of Nairobi.

Sood, P. B., \&Medury, Y. (2012).Investment preferences of salaried individuals towards financial products.International Journal of Management and Behavioural Sciences, 1(1), 95-107

Usman, D. I. (2018). Influence of Cognitive Biases on Investment Decision Making in Property Market in Plateau State, Nigeria. Doctoral Thesis, Jomo Kenyatta University of Agriculture and Technology.

Waweru, N. M., Munyoki, E., \& Uliana, E. (2008). The effects of behavioural factors in investment decision-making: a survey of institutional investors operating at the Nairobi Stock Exchange. International Journal of Business and Emerging Markets, 1(1), 24-41.

Zait, A., \& Bertea, P. E. (2015). Financial literacyConceptual definition and proposed approach for a measurement instrument. The Journal of Accounting and Management, 4(3), 37-42.

Zikmund, W. G., Babin, B. J., Carr, J. C., \& Griffin, M. (2010). Business research methods (8th ed.). Mason, HO: Cengage Learning 